\title{
A case of thyrotoxicosis-induced anemia in a patient with painless thyroiditis
}

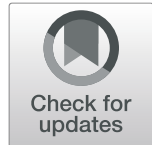

Ichiro Komiya ${ }^{1,2^{*}}$, Takeaki Tomoyose ${ }^{3}$, Noriharu Yagi ${ }^{2}$, Gen Ouchi ${ }^{4}$ and Tamio Wakugami ${ }^{1}$

\begin{abstract}
Background: There have been several reports of secondary anemia associated with Graves' disease. There are no reports of secondary anemia resulting from thyrotoxicosis due to painless thyroiditis (silent thyroiditis). We report the case of a patient with pancreatic diabetes who developed anemia caused by thyrotoxicosis due to painless thyroiditis.
\end{abstract}

Case presentation: The patient was a 37-year-old man who visited the hospital complaining of fatigue, palpitations, and dyspnea. His hemoglobin was $110 \mathrm{~g} / \mathrm{l}$ (reference range, 135-176), and mean corpuscular volume was $81.5 \mathrm{fl}(81.7-101.6)$. His free thyroxine (FT4) was high, at $100.4 \mathrm{pmol} / \mathrm{I}(11.6-21.9)$; the free triiodothyronine (FT3) was high, at $27.49 \mathrm{pmol} / \mathrm{l}(3.53-6.14)$; TSH was low, at < $0.01 \mathrm{mIU} / \mathrm{l}(0.50-5.00)$; and TSH receptor antibody was negative. Soluble IL-2 receptor (sIL-2R) was high, at $1340 \mathrm{U} / \mathrm{ml}(122-496) ;$ C-reactive protein (CRP) was high, at $6900 \mathrm{\mu g} / \mathrm{l}(<3000) ;$ and reticulocytes was high, at $10810^{9} / 1$ (30-100). Serum iron (Fe) was 9.5 (9.1-35.5), ferritin was $389 \mu \mathrm{g} / \mathrm{l}$ (13-401), haptoglobin was $0.66 \mathrm{~g} / \mathrm{l}$ (0.19-1.70. Propranolol was prescribed and followed up. Anemia completely disappeared by 12 weeks after disease onset. Thyroid hormones and sIL-2R had normalized by 16 weeks after onset. He developed mild hypothyroidism and was treated with L-thyroxine at 24 weeks.

Conclusions: This is the first case report of transient secondary anemia associated with thyrotoxicosis due to painless thyroiditis. The change in sIL-2R was also observed during the clinical course of thyrotoxicosis and anemia, suggesting the immune processes in thyroid gland and bone marrow.

Keywords: Painless thyroiditis, Anemia, silL-2R, And thyrotoxicosis

\section{Background}

Secondary anemia associated with hyperthyroidism is a relatively rare complication [1]. Many reports have shown that although anemia progresses with hyperthyroidism in Graves' disease, it is often transient, improving with treatment of Graves' disease [2-4]. There are no reports of secondary anemia resulting from thyrotoxicosis due to subacute thyroiditis, painless thyroiditis (silent thyroiditis) [5], or other causes. Here, we report a case of transient

\footnotetext{
* Correspondence: i.kom.iya@nifty.com

'Department of Internal Medicine, Okinawa Medical Hospital, 2310

Tsuhako-Nishihara, Sashiki, Nanjo, Okinawa 9011414, Japan

${ }^{2}$ Yagi Internal Medicine Clinic, 4-13-9 Kohagura, Naha, Okinawa 9000029, Japan

Full list of author information is available at the end of the article
}

anemia that developed after the onset of painless thyroiditis in a patient with pancreatic diabetes treated with insulin.

\section{Case presentation}

A 37-year-old man visited our hospital due to gradually progressive fatigue, dyspnea, and palpitations of approximately 14 days duration. His pulse was 104 beats/min, and his body temperature was $36.8^{\circ} \mathrm{C}$. No increase in sweating was observed, goiter was not palpable, and no exophthalmos or ocular movement dysfunction was observed. Laboratory examination showed anemia ( $\mathrm{Hgb}$ $110 \mathrm{~g} / \mathrm{l}$ [reference rage, 135-176], mean corpuscular volume [MCV] $81.5 \mathrm{fl}$ [81.7-101.6]), and serum iron $(9.5 \mu \mathrm{mol} / \mathrm{l})$ and ferritin $(389 \mu \mathrm{g} / \mathrm{l})$ were within the

(c) The Author(s). 2021 Open Access This article is licensed under a Creative Commons Attribution 4.0 International License, which permits use, sharing, adaptation, distribution and reproduction in any medium or format, as long as you give appropriate credit to the original author(s) and the source, provide a link to the Creative Commons licence, and indicate if changes were made. The images or other third party material in this article are included in the article's Creative Commons licence, unless indicated otherwise in a credit line to the material. If material is not included in the article's Creative Commons licence and your intended use is not permitted by statutory regulation or exceeds the permitted use, you will need to obtain permission directly from the copyright holder. To view a copy of this licence, visit http://creativecommons.org/licenses/by/4.0/ The Creative Commons Public Domain Dedication waiver (http://creativecommons.org/publicdomain/zero/1.0/) applies to the data made available in this article, unless otherwise stated in a credit line to the data. 
normal ranges. Reticulocytes were increased at the time of onset (108 $10^{9} / \mathrm{l}$; reference rage, 30-100), C-reactive protein $(\mathrm{CRP})$ was $6900 \mu \mathrm{g} / \mathrm{l}(<3000)$, and his haptoglobin was within normal range $(0.66 \mathrm{~g} / \mathrm{l}$; reference range, $0.19-1.70$ ). The FT4 (free thyroxine) level was high, at $100.4 \mathrm{pmol} / \mathrm{l}$ (11.6-21.9), the FT3 (free triiodothyronine) level was high, at $27.49 \mathrm{pmol} / \mathrm{l}(3.53-6.14)$, and his TSH was $<0.01 \mathrm{mIU} / \mathrm{l}(0.50-5.00)$. TSH receptor antibody, anti-TPO antibody or anti-thyroglobulin antibody were negative. In other clinical tests, soluble interleukin-2 receptor (sIL-2R), measured for differentiation of hematologic malignancies, was high, at $1340 \mathrm{U} / \mathrm{ml}(122-$ 496); his low-density lipoprotein cholesterol (LDL-C) was low, at $0.78 \mathrm{mmol} / \mathrm{l}(1.68-3.59)$; and his highdensity lipoprotein cholesterol (HDL-C) was low, at $0.75 \mathrm{mmol} / \mathrm{l}$ (1.03-2.48) (Table 1).

The patient was previously diagnosed with pancreatic diabetes due to alcoholic pancreatitis at age 25 years, and thus, he was treated with a combination of insulin glargine and insulin aspart. Regular clinical examinations were performed every 28 days, and no abnormalities were found in his biochemical data or complete blood count, other than his plasma glucose and HbA1c. Propranolol ( $30 \mathrm{mg} /$ day) was prescribed at day 14 and stopped on day 56. Thyroid ultrasonography was performed on day 28, and hypoechoic regions were observed throughout the thyroid gland (Fig. 1).

The anemia disappeared by day 84 . The patient's thyroid hormones and sIL-2R normalized by day 112 , and CRP normalized by day 140 . The clinical courses of Hgb, FT4, and sIL-2R were shown in Fig. 2. There was slight decrease in LDL-C and HDL-C, and increases in liver enzymes at disease onset, but these changes disappeared by day 140 (Table 1). His serum albumin was low at onset but normalized by day 140 . The patient's insulin regimen was not changed over the entire clinical course. He developed mild hypothyroidism on day 112 and was started on $12.5 \mu \mathrm{g}$ of L-thyroxine replacement therapy on day 168 (Table 1 ).

\section{Discussion and conclusions}

We reported a case of painless thyroiditis-induced thyrotoxicosis that suddenly led to anemia within 4 weeks after the patient's last visit to our hospital. Although it was not possible to prove reduced iodine uptake using thyroid scintigram, negative TSH receptor antibody, the mild increase of CRP, lack of tenderness in thyroid gland, and the diffuse destructive findings on thyroid ultrasonography indicated painless thyroiditis [5]. In addition, FT3/FT4 ratio (0.301) was low, suggesting painless thyroiditis, because the median (IQR) of FT3/FT4 ratio in painless thyroiditis was reported as $0.310(0.203-0.608)$ [6]. This is the first report of secondary anemia associated with painless thyroiditis. Although the levels remained within the normal range, slight decrease in $\mathrm{WBC}$ and platelets presented at disease onset [1]. Anemia, and the decrease in WBC and platelets completely disappeared by 12 weeks after onset, with spontaneous remission of thyrotoxicosis.

In addition to the clinical course of thyrotoxicosis and associated anemia, the present case provided interesting laboratory data. First, sIL-2R was high at onset but normalized by 16 weeks after onset of anemia. Elevated levels of sIL-2R have been reported in hyperthyroidism of Graves' disease and it was suggested that thyroid hormones directly enhance sIL-2R production in lymphocytes [7]. The levels in sIL-2R also increased in patients with the thyrotoxicosis due to painless thyroiditis [8]. Second, LDL-C and HDL-C levels decreased due to thyrotoxicosis. Excessive thyroid hormone levels lower serum LDL-C and HDL-C levels via several mechanisms [9-11]. We previously reported that increased sIL-2R cause significant decreases levels in HDL-C and LDL-C in patients with hematologic malignancies [12]. Increased cytokines were recently reported to be associated with hypolipidemia in COVID-19 patients [13]. Presumably, increases in levels of both thyroid hormones and sIL-2R are associated with the decreases in HDL-C and LDL-C.

Painless thyroiditis (silent thyroiditis) is a self-limiting inflammatory disorder of the thyroid gland characterized by an early thyrotoxicosis phase caused by the release of thyroid hormones and a late hypothyroidism phase, with complete resolution in most cases $[5,14]$. The pathophysiologic mechanism of painless thyroiditis is unknown, but the possibility of immune disorder involvement has been suggested $[5,7,8,15]$. Painless thyroiditis generally manifests as a lymphocyte infiltration of the thyroid follicles, causing thyroid follicular cell damage [5]. In our case, we observed a typical course of painless thyroiditis. The secondary anemia caused by thyrotoxicosis has improved, but we would like to carefully follow up on the continuation of thyroid hormone replacement therapy.

The mechanism by which anemia develops in thyrotoxicosis is not clear. Shortened erythrocyte survival or ineffective erythropoiesis have been suggested as potential causes of anemia in thyrotoxicosis [2-4]. Moreover, slight decrease in WBC and platelets was observed in present case, which could have been due to a variety of mechanisms. The involvement of autoantibodies in leukocytes and platelets resulting in increased destruction of hematopoietic cells by immunological mechanisms has been reported [16]. The increase in sIL-2R, which had been increasing at the onset of painless thyroiditis, may suggest the result of immune process abnormality rather than the increase in thyroid hormones [8, 17]. The involvement of immune processes in the onset of painless thyroiditis could help explain the 
Table 1 Profile of laboratory data for a diabetes patient with thyrotoxicosis due to painless thyroiditis

\begin{tabular}{|c|c|c|c|c|c|c|c|c|c|c|c|}
\hline Variables & $\begin{array}{l}\text { Reference } \\
\text { range }\end{array}$ & $\begin{array}{l}\text { Day - } \\
56\end{array}$ & $\begin{array}{l}\text { Day } \\
-28\end{array}$ & $\begin{array}{l}\text { Day } \\
0\end{array}$ & Day 14 & Day 28 & $\begin{array}{l}\text { Day } \\
56\end{array}$ & $\begin{array}{l}\text { Day } \\
84\end{array}$ & $\begin{array}{l}\text { Day } \\
112\end{array}$ & $\begin{array}{l}\text { Day } \\
140\end{array}$ & $\begin{array}{l}\text { Day } \\
168\end{array}$ \\
\hline Red blood cells, $10^{12} / \mathrm{I}$ & $4.27-5.70$ & 4.80 & 4.96 & 3.78 & 3.77 & 3.84 & 4.50 & 4.77 & 4.93 & 4.88 & 4.66 \\
\hline Hemoglobin (Hgb), g/l & $135-176$ & 144 & 146 & 110 & 107 & 109 & 126 & 136 & 142 & 146 & 140 \\
\hline Hematocrit (Hct), /l & $0.398-0.518$ & 0.399 & 0.408 & 0.308 & 0.305 & 0.306 & 0.352 & 0.377 & 0.392 & 0.386 & 0.408 \\
\hline Mean corpuscular volume (MCV), fl & $81.7-101.6$ & 83.1 & 82.3 & 81.5 & 80.9 & 79.7 & 78.2 & 79.0 & 79.5 & 82.8 & 83.4 \\
\hline White blood cells (WBC), $10^{9} / \mathrm{I}$ & $3.5-9.8$ & 6.4 & 7.4 & 5.3 & 7.2 & 6.5 & 8.8 & 8.6 & 8.8 & 5.8 & 7.4 \\
\hline Platelets, $10^{9} / \mathrm{I}$ & $130-369$ & 272 & 315 & 254 & 198 & 228 & 289 & 266 & 283 & 322 & 333 \\
\hline Reticulocytes, $10^{9} / \mathrm{I}$ & $30-100$ & & & 108 & 68 & & & & & & \\
\hline $\begin{array}{l}\text { Thyroid stimulating hormone } \\
\text { (TSH), mIU/I }\end{array}$ & $0.50-5.00$ & & & $\begin{array}{l}< \\
0.01\end{array}$ & $<0.01$ & $<0.01$ & $\begin{array}{l}< \\
0.01\end{array}$ & & 10.1 & 15.2 & 18.5 \\
\hline Free triiodothyronine (FT3), pmol/l & $3.53-6.14$ & & & & 27.49 & 12.61 & 9.37 & & 3.93 & 4.35 & 4.22 \\
\hline Free thyroxine (FT4), pmol/l & $11.6-21.9$ & & & 100.4 & 91.4 & 51.5 & 33.1 & & 14.0 & 13.1 & 14.0 \\
\hline $\begin{array}{l}\text { TSH receptor antibody (TRAb), } \\
\text { mIU/l }\end{array}$ & $<2.0$ & & & & 0.4 & & & & & & \\
\hline Anti-TPO antibody, IU/ml & $<16$ & & & & 9 & & & & & & \\
\hline Ant-thyroglobulin antibody, IU/ml & $<28$ & & & & 11 & & & & & & \\
\hline C-reactive protein (CRP), $\mu \mathrm{g} / \mathrm{l}$ & $<3000$ & & & 6900 & & 12,100 & 5700 & 3700 & & 1200 & \\
\hline Iron (Fe), $\mu \mathrm{mol} / / \mathrm{l}$ & $9.1-35.5$ & & & 9.5 & & 9.5 & & & & & \\
\hline $\mathrm{TIBC}, \mu \mathrm{mol} / \mathrm{l}$ & $43.2-69.0$ & & & 34.2 & & 40.8 & & & & & \\
\hline Ferritin, $\mu \mathrm{g} / \mathrm{l}$ & $13-401$ & & & 389 & & 376 & 396 & & & & \\
\hline Haptoglobin, g/dl & $0.19-1.70$ & & & 0.66 & & & & & & & \\
\hline Soluble IL-2 receptor (sIL-2R), U/ml & $122-496$ & & & 1340 & & 1010 & 808 & & 472 & & 365 \\
\hline $\mathrm{HDL}-\mathrm{C}, \mathrm{mmol} / \mathrm{l}$ & $1.03-2.48$ & 1.27 & 1.09 & 0.75 & & 0.98 & 1.27 & 1.42 & 1.14 & 1.16 & 1.14 \\
\hline LDL-C, mmol/l & $1.68-3.59$ & 1.99 & 1.63 & 0.78 & & 1.45 & 2.12 & 2.82 & 2.87 & 2.90 & 2.82 \\
\hline Triglycerides (TG), mmol/l & $0.34-1.68$ & 0.46 & 0.59 & 0.54 & & 0.84 & 0.68 & 0.75 & 0.84 & 0.59 & 0.60 \\
\hline $\mathrm{HbA1c}(\mathrm{NGSP}), \%$ & $4.6-6.2$ & 6.9 & 7.1 & 7.6 & & 6.5 & 6.6 & 6.9 & 7.7 & 7.6 & 7.5 \\
\hline AST, IU/I & $13-33$ & 19 & 18 & 21 & & 25 & 30 & 25 & 22 & 27 & 23 \\
\hline $\mathrm{ALT}, \mathrm{IU} / \mathrm{I}$ & $6-30$ & 13 & 14 & 19 & & 28 & 29 & 21 & 15 & 22 & 21 \\
\hline YGTP, IU/I & $10-47$ & 13 & 14 & 21 & & 42 & 57 & 37 & 26 & 20 & 19 \\
\hline Albumin, $g / l$ & $40-50$ & 41 & 42 & 31 & & 32 & 36 & 36 & 35 & 41 & 41 \\
\hline $\mathrm{eGFR}, \mathrm{ml} / \mathrm{min} / 1.73 \mathrm{~m}^{2}$ & $>60$ & 103 & 97 & 111 & & 115 & 104 & 90 & 88 & 79.0 & 80.0 \\
\hline Drug treatment & & & & & $\begin{array}{l}\text { Propranolol } \\
30 \mathrm{mg}\end{array}$ & $\begin{array}{l}\text { Propranolol } \\
30 \mathrm{mg}\end{array}$ & & & & & $\begin{array}{l}\mathrm{LT} 4 \\
12.5 \mu \mathrm{g}\end{array}$ \\
\hline
\end{tabular}

Bold data is abnormal value. eGFR estimated glomerular filtration rate

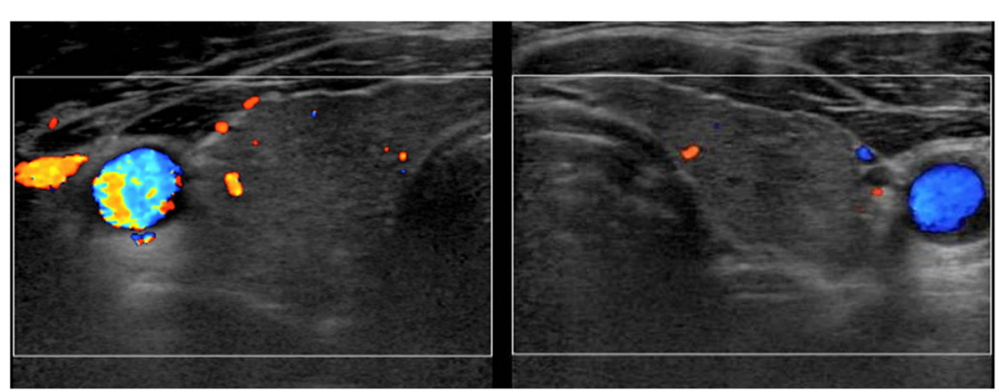

Fig. 1 Thyroid ultrasonography findings. Hypoechoic regions are scattered throughout the thyroid gland. No increase in blood flow in the thyroid gland was observed 


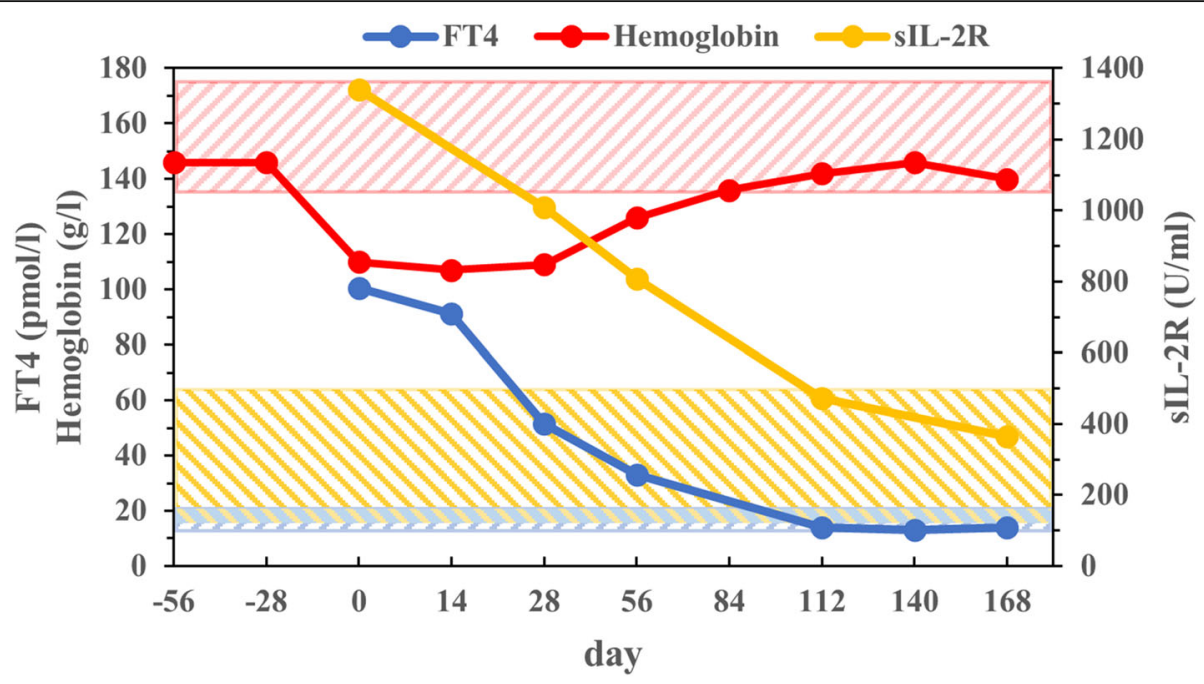

Fig. 2 Profile of FT4, hemoglobin, and sIL-2R. The patient's hemoglobin had normalized by day 84. FT4 and sIL-2R returned to be normal by day 112. The shaded area shows the reference range for each variable

pathophysiology of anemia [18]. In present case, however, both anti-TG and anti-TPO antibodies were negative. Anti-thyroglobulin and anti-TPO antibodies prevalence in painless thyroiditis have been reported to be 70 and 30\%, respectively [19]. The patient had an history of acute pancreatitis. It is interesting to assume the immune mechanisms as the pathogenesis of acute and chronic pancreatitis [20], and it is natural to assume that the immune mechanism was involved in the development of silent thyroiditis and anemia in present case.

In conclusion, we reported the case of a diabetes patient with secondary anemia resulting from thyrotoxicosis. Thyrotoxicosis was caused by painless thyroiditis, but there have been no reports of secondary anemia induced by painless thyroiditis. The change in SIL-2R was also observed during the clinical course of thyrotoxicosis and anemia.

\section{Abbreviations}

TSH: Thyroid stimulating hormone; FT4: Free thyroxine; FT3: Free triiodothyronine; sIL-2R: Soluble interleukin-2 receptor; HDL-C: High-density lipoprotein cholesterol; LDL-C: Low-density lipoprotein cholesterol

\section{Acknowledgements}

We would like to thank FORTE (www.forte-science.co.jp) for English language editing.

\section{Authors' contributions}

TW has full access to all of the data from the study and takes responsibility for the integrity of the data. IK and $T T$ were involved in study design, interpreting data, statistical analysis, creating tables and figures, and drafting the manuscript. NY and GO were involved in interpreting data and supervised the work. All authors have contributed significantly to this work. All the authors have read the manuscript and have approved this submission.

\section{Funding}

The authors received no specific funding for this work.
Availability of data and materials

The collection of data that supports the findings in this study is available from Okinawa Medical Hospital. Data are available from the authors upon reasonable request and with permission of Okinawa Medical Hospital.

\section{Declarations}

Ethics approval and consent to participate

No applicable.

\section{Consent for publication}

Regarding publication of the case report, we explained that we could not reveal personal information and obtained verbal consent from the patient.

\section{Competing interests}

The authors declare no conflict of interest.

\section{Author details}

'Department of Internal Medicine, Okinawa Medical Hospital, 2310 Tsuhako-Nishihara, Sashiki, Nanjo, Okinawa 9011414, Japan. ${ }^{2}$ Yagi Internal Medicine Clinic, 4-13-9 Kohagura, Naha, Okinawa 9000029, Japan. ${ }^{3}$ Department of Hematology, Okinawa Red Cross Hospital, 1-3-1 Yogi, Naha, Okinawa 9028588, Japan. ${ }^{4}$ Department of Emergency and Critical Care Medicine, University of Ryukyus Hospital, 207 Uehara, Nishihara, Okinawa 9030215, Japan.

Received: 16 December 2020 Accepted: 11 April 2021

Published online: 23 April 2021

\section{References}

1. Ford HC, Carter JM. The haematology of hyperthyroidism: abnormalities of erythrocytes, leucocytes, thrombocytes and haemostasis. Postgrad Med J. 1998;64:735-42.

2. Szczepanek-Parulska E, Hernik A, Ruchała M. Anemia in thyroid diseases. Pol Arch Intern Med. 2017;127(5):352-60. https://doi.org/10.20452/pamw.3985.

3. Gianoukakis AG, Leigh MJ, Richards P, Christenson PD, Hakimian A, Fu P, et al. Characterization of the anaemia associated with Graves' disease. Clin Endocrinol (Oxf). 2009;70:781-7.

4. Das KC, Mukherjee M, Sarkar TK, Dash RJ, Rastogi GK. Erythropoiesis and erythropoietin in hypo- and hyperthyroidism. J Clin Endocrinol Metab. 1975; 40(2):211-20. https://doi.org/10.1210/jcem-40-2-211.

5. Mizukami Y, Michigishi T, Hashimoto T, Tonami N, Hisada K, Matsubara F, et al. Silent thyroiditis: a histologic and immunohistochemical study. Hum Pathol. 1988;19(4):423-31. https://doi.org/10.1016/50046-8177(88)80492-1. 
6. Yoshimura JN, Momotani N, Fukada S, Ito K, Miyauchi A, Amino N. Ratio of serum free triiodothyronine to free thyroxine in Graves' hyperthyroidism and thyrotoxicosis caused by painless thyroiditis. Endocr J. 2005;52(5):53742. https://doi.org/10.1507/endocri.52.537.

7. Koukkou E, Panayiotidis P, Alevizou-Terzaki V, Thalassinos N. High levels of serum soluble interleukin-2 receptors in hyperthyroid patients: correlation with serum thyroid hormones and independence from the etiology of the hyperthyroidism. J Clin Endocrinol Metab. 1991;73(4):771-6. https://doi.org/1 0.1210/jcem-73-4-771.

8. Hamamoto K, Inaba M, Yamada S, Yoda M, Yoda K, Goto H, et al. Increased soluble IL-2 receptor levels in serum from a patient with painless thyroiditis. Thyroid Res. 2013;6(1):12. https://doi.org/10.1186/1756-6614-6-12.

9. Lopez D, Socarrás JFA, Bedi M, Ness GC. Activation of the hepatic LDL receptor promoter by thyroid hormone. Biochim Biophys Acta. 1771;2007: 1216-25.

10. Bonde Y, Breuer O, Lütjohann D, Sjöberg S, Angelin B, Rudling M. Thyroid hormone reduces PCSK9 and stimulates bile acid synthesis in humans. J Lipid Res. 2014;55(11):2408-15. https://doi.org/10.1194/jlr.M051664.

11. Tan KC, Shiu SW, Kung AW. Plasma cholesteryl ester transfer protein activity in hyper- and hypothyroidism. J Clin Endocrinol Metab. 1998;83(1):140-3. https://doi.org/10.1210/jcem.83.1.4491.

12. Komiya I, Tomoyose T, Ouchi G, Yara T, Higa S. Low level of serum HDLcholesterol with increased sIL-2R predicts a poor clinical outcome for patients with malignant lymphoma and adult T-cell leukemia-lymphoma. Cytokine. 2018;105:57-62. https://doi.org/10.1016/j.cyto.2018.02.005.

13. Wei X, Zeng W, Su J, Wan H, Yu X, Cao X, et al. Hypolipidemia is associated with the severity of COVID-19. J Clin Lipidol. 2020;14(3):297-304. https://doi. org/10.1016/j.jacl.2020.04.008.

14. Strakosch CR. Thyroiditis. Aust NZ J Med. 1986;16(1):91-100. https://doi.org/1 0.1111/j.1445-5994.1986.tb01138.x.

15. Takasu N, Komiya I, Nagasawa Y, Asawa T, Yamada T. Exacerbation of autoimmune thyroid dysfunction after unilateral adrenalectomy in patients with Cushing's syndrome due to an adrenocortical adenoma. N Engl J Med. 1990;322(24):1708-12. https://doi.org/10.1056/NEJM199006143222404.

16. Garla W, Salim SA, Yanes-Cardozo LL. Pancytopenia: a rare complication of Graves' disease. BMJ Case Rep. 2018;2018:bcr2017223887.

17. Dik WA, Heron M. Clinical significance of soluble interleukin-2 receptor measurement in immune-mediated diseases. Neth J Med. 2020;78(5):220-31.

18. Nobili V, Liaskos C, Luigi G, Guidi R, Francalanci P, Marcellini M. Autoimmune thyroiditis associated with autoimmune hepatitis. Thyroid. 2005;15(10):11935. https://doi.org/10.1089/thy.2005.15.1193.

19. Nishihara E, Amino N, Kudo T, Ito M, Fukata S, Nishikawa M, et al. Comparison of thyroglobulin and thyroid peroxidase antibodies measured by five different kits in autoimmune thyroid diseases. Endocr J. 2017;64(10): 955-61. https://doi.org/10.1507/endocrj.E17-0164.

20. Lee B, Zhao Q, Habtezion A. Immunology of pancreatitis and environmental factors. Curr Opin Gastroenterol. 2017;33(5):383-9. https://doi.org/10.1097/ MOG.0000000000000387.

\section{Publisher's Note}

Springer Nature remains neutral with regard to jurisdictional claims in published maps and institutional affiliations.

Ready to submit your research? Choose BMC and benefit from:
- fast, convenient online submission
- thorough peer review by experienced researchers in your field
- rapid publication on acceptance
- support for research data, including large and complex data types
- gold Open Access which fosters wider collaboration and increased citations
- maximum visibility for your research: over 100M website views per year
At BMC, research is always in progress.
Learn more biomedcentral.com/submissions

